their cattle while others went west across the Semliki. In Kitara the Bahutu were subject to the Batutsi, who had already adopted their language; and quite easily they were again dominated by the Batutsi in Ruanda-Urundi: ' Les Bahutu ne faisaient que retrouver leurs anciens maitres.' M. Simons acknowledges that this theory may have its weak points; but he thinks it explains the identity of language between Hamitic and Bantu peoples in RuandaUrundi and in the Ituri region, and the similarity between their customs and institutions. The assimilation of the two groups is more easily understood if we suppose that for long periods they had lived in contact before the migration: 200 years is too short a time for such complete assimilation. The Bahema have been in the Ituri region for the same period and remain distinct from the neighbouring tribes in language and customs. As for the Batwa, M. Simons still regards them as descended from the aboriginal inhabitants of Urundi.

\title{
Industrial Conditions in Nigeria
}

THE first inquiry conducted by the Labour Advisory Board of Lagos revealed a sad state of affairs in the tailoring industry. Factories employing several hundred workers and organized on European lines were inspected as well as numerous small shops set up in small back rooms. Deplorable aspects of sweated labour were revealed and in particular the existence of exploited child labour. Mere children, dubbed 'apprentices', aged from eight years upwards, were found to be working without wages, while others received ' gifts' of a few pence per week. Hours of work were virtually unlimited. In many cases small children could be seen working by the dim light of oil lamps well after midnight on Sunday nights. In ' rush' times employees might be forced to remain in the workshops six nights in succession. Work would continue without intermission until, overcome by sheer exhaustion, the worker fell asleep; he would be allowed to slumber for a short time and then be awakened to go on with his task. Few employers considered themselves responsible for the health and welfare of their employees. In a word, some of the worst evils of the English Industrial Revolution were being reproduced by Africans under the tropical sun. From I April this year the Nigerian Government has enforced drastic reforms as a result of the Board's inquiry.

\section{Sotho Literature}

IN African Studies for December 1944 Mr. G. L. Letele, lecturer in Sotho languages at Fort Hare, reviews publications which have appeared in Tswana and Sotho (northern and southern) during the period 1939-43. He lists twenty-one books in all: poetry, drama, prose fiction, history, and travel; with two or three exceptions the writers are Africans. For readers who have not seen the books, or could not read them if they had seen them, Mr. Letele's critical comments are illuminating. It is notable that the favourite themes of the novelists are the adventures of young men and women who go off to the towns and mines with the belief xo sepela ke xo bona, 'to travel is to see'. Mr. Letele is disappointed with E. Motsamai Leoatle's biography of Moshweshwe, the founder of the Sotho nation, on the ground that he has failed to delineate the intimate side of the Chief's life. Old men who knew him are fast passing away and in a few years' time it will be impossible to collect personal details. Will not some Mosuto do for Moshweshwe what Thomas Mofolo did for Chaka? This biography was a best-seller among the books published by the Institute. 